\title{
CAPítTLLO 3
}

\section{O JOGO EM AÇÃO OS ACORDOS DE LENIÊNCIA DO MINISTÉRIO PÚBLICO FEDERAL}

A Lei Anticorrupção entrou em vigor quase concomitantemente às fases públicas da Lava Jato que se iniciaram em março de 2014. Então, somada à ambiguidade da Lei Anticorrupção e sua sobreposição com outros subsistemas de responsabilização de pessoas jurídicas, descritos no capítulo anterior, há um contexto político que restringirá e habilitará a ação dos atores sobre o instrumento. Mais ainda: é um contexto de turbulências.

Já em 2014 os investigadores se depararam com a natureza multifacetada do problema que iriam enfrentar. Corrupção, cartel e lavagem de dinheiro eram temas imbricados. Ainda em 2014, começou-se a identificar um cartel que dividia o mercado de obras contratadas pela Petrobras. Este cartel operou desde o final dos anos 1990 até as investigações se iniciarem. ${ }^{1}$ As empresas fixavam preços, condições, vantagens e abstenção de participação de rodadas de licitação e dividiam as obras entre si. Inicialmente, o cartel era composto por nove

\footnotetext{
Histórico da Conduta SOG Óleo e Gás, Versão Pública, parte do acordo de leniência celebrado entre a empresa e a Superintendência-Geral do Conselho Administrativo de Defesa Econômica em 19 de março de 2015. Disponível em: http://www.cade.gov.br/noticias/cade-celebra-acordo-de-leniencia-no-ambito-da-201coperacao-lava-jato201d/hc-versao_publica. pdf. Último acesso em: 15 dez. 2018.
} 
empresas e, depois, expandido para dezesseis, sendo que outros agentes de mercado participavam esporadicamente da colusão. ${ }^{2}$

Para garantir sua estabilidade e para quem outros agentes não entrassem no mercado, eram feitos pagamentos ilícitos para membros da diretoria da Petrobras, capazes de controlar quem era convidado ou habilitado a apresentar propostas em licitações da empresa. ${ }^{3} \mathrm{O}$ vencedor do contrato supostamente também acertaria propinas dentro do contrato licitado. Esses recursos, ao serem remetidos para indivíduos passariam, em tese, por camadas de operações de lavagem de dinheiro em diversos países, por meio de offshores. ${ }^{4}$

Ou seja, corrupção era um mecanismo de manutenção do cartel, que se prolongava na relação entre empresa licitada e agente público, valendo-se, por vezes, de uma complexa rede de lavagem de recursos. Tão importante quanto os fatos desvelados, é o fato de que eles emergem em contexto de mudanças legislativas que sinalizam novas possibilidades de acordos entre autoridades e agentes privados em processos sancionatórios - para pessoas jurídicas, como discutimos no capítulo anterior, mas também para pessoas físicas, com a Lei de Organizações Criminosas, também de 2013. Novas legislações e investigações criaram um ambiente distinto que passa a influenciar a tomada de decisão dos agentes. Nas palavras do advogado Arthur Badin: ${ }^{5}$

\footnotetext{
“(...) as novas legislações (...) que foram aprovados em 2013 sinalizaram um novo ordenamento, uma nova forma de lidar com situações de desvios de conduta das empresas. Historicamente, [elas] estavam acostumadas a 'enfiar a cabeça embaixo da areia'. Poucas perceberam com a Lava Jato essa mudança de ambiente de incentivos jurídicos para a colaboração. Todo mundo ainda apostava em resistir às investigações."
}

É neste cenário de avanços de investigações e de novos instrumentos que as autoridades, especialmente o MPF, começarão a pensar sua atuação.

2 Ibid., p. 1. O clube das 9 era composto pelas seguintes empresas Camargo Corrêa S.A., Construtora Andrade Gutierrez S.A., Construtora Norberto Odebrecht S.A., Mendes Junior Trading Engenharia, MPE Montagens e Projetos Especiais S.A., Promon S.A., Setal/SOG Óleo e Gás, Techint Engenharia e Construção S.A. e UTC Engenharia S.A.. O clube das 16 passou a incluir também: Construtora OAS S.A., Engevix Engenharia, Galvão Engenharia S.A., GDK S.A., IESA Óleo e Gás, Queiroz Galvão Óleo e Gás e Skanska Brasil Ltda.

3 Ibid., p. 21.

4 Ver sentença proferida pela $13^{\mathrm{a}}$ Vara Federal da Justiça Federal em Curitiba, em 8 de março de 2016, Ação Penal nº. 503652823.2015.4.04.7000/PR.

5 BADIN, Arthur, Entrevista, São Paulo, 11 out. 2018. MP3. 


\title{
1. 0 CONTEXTO E INTERPRETAÇ̃̃ES QUE HABILITAM A ATUAC̦ÃO dO MPF
}

\author{
A relação entre cartel e corrupção impulsionou o MPF a começar a pensar \\ em fazer acordos de leniência próprios. O relato do Procurador da República \\ Carlos Fernando dos Santos Lima, à época integrante da Força Tarefa da Lava \\ Jato em Curitiba explica: ${ }^{6}$
}

“(...) essa ideia de leniência nem passava pela nossa cabeça. Mas diante da natureza das nossas investigações, nós estávamos com questões de Direito Econômico, era um cartel das empreiteiras e nós tínhamos um colaborador que falava sobre esse cartel. Então de alguma forma nós nos aproximamos do CADE. (...) E nesse episódio de aproximação com o CADE, eu comecei a ler a respeito dos acordos de leniência. Eu li os do CADE e os da Lei Anticorrupção e cheguei à conclusão que era possível que o MP tivesse um papel importante a desenvolver nesses acordos. (...) Não sei se você sabe, mas eu e o Vladimir Aras desenvolvemos os primeiros acordos de colaboração premiada em crimes de colarinho branco, ainda em 2003, ainda quando não existia legislação. (...) Então nós já tínhamos uma experiência de que muitas vezes o sistema, a legislação diretamente não nos dava esse papel, mas que era possível construir dentro do sistema uma interpretação de que nós tínhamos um papel primeiro nas colaborações de colarinho branco e agora na leniência, porque era evidente que a Lei Anticorrupção era frágil, ela não tinha elementos suficientes para atrair a empresa para um acordo. (...) Por quê? Porque no Brasil existe, sobre o fato desse tipo de crime de colarinho branco, especialmente sobre a investigação da Lava Jato, a empresa está envolvida em crimes financeiros, crimes econômicos, crimes tributários, corrupção, lavagem de dinheiro e a Lei Anticorrupção não resolve o problema ou não dava um arcabouço suficientemente bom para incentivar a empresa a vir. Além disso, ela só tratava das multas da Lei Anticorrupção. Como tem todo esse arcabouço de incidências jurídicas de diversas pessoas e ordenamentos diferentes, a pessoa se sujeitava, se revelasse os fatos, a multas de diversas ordens e à penalização criminal dos seus principais agentes, que, no caso do Brasil, diferente dos EUA, são normalmente familiares, donos das empresas. Como nós temos uma estrutura societária normalmente de empresas familiares, qual era o incentivo da empresa revelar algo que correspondia, na verdade, a um crime dos seus proprietários e que, ao mesmo tempo, não dava nenhuma proteção? Nesse ponto, a lei do CADE tem uma estrutura melhor porque dá essa proteção penal. Aí, observando a prática do CADE, eu observei que, apesar da lei não falar nada sobre intervenção do MP, o CADE chama o MP para assinar os acordos. (...) Mas se não estava lá, minha primeira pergunta [era] por que o MP estava intervindo se ele não está na lei? Se ele não está lá, eu também não estou aqui, mas se ele vai lá, eu também posso ir aqui. O raciocínio jurídico não é de muita complexidade. Eu já tinha a experiência de que se você tem um arcabouço do sistema que suporte e você tem um bom motivo, que no caso eram as investigações da Lava Jato, você deve tentar. Então nós resolvemos, basicamente eu resolvi, fazer esse acordo e convenci os colegas."

Para ele, a experiência do CADE era relevante de duas formas. Primeiro, por ter incentivos adequados, estendendo os efeitos dos acordos de leniência para

6 LIMA, Carlos F S., Entrevista, Curitiba, 22 out. 2018. MP3. 
conceder imunidade criminal a pessoas físicas, conforme o art. 87 da Lei Antitruste. ${ }^{7}$ Segundo, pela prática de chamar o MP para assinar os acordos do CADE desde o início do programa de leniência, ainda que o Ministério Público não seja mencionado na legislação antitruste. Essa foi uma construção fundamental para viabilização do instrumento, como explica Badin, Presidente do CADE à época do início do programa de leniência antitruste: ${ }^{8}$

\begin{abstract}
"A grande preocupação que eu tinha em 2003 ao celebrar e negociar o primeiro acordo [de leniência antitruste] era: a lei era clara, a celebração do acordo de leniência impede a propositura da ação penal, e uma vez cumprido o acordo, extingue-se a punibilidade penal. Não tem dúvida, isso está escrito na lei. Agora, a grande preocupação que a gente tinha era 'quem disse que o MPF vai honrar esse compromisso, vai respeitar, não vai entrar com uma ação dizendo, este acordo não é válido?' (...) Se isso acontecesse, o programa de leniência no Brasil seria natimorto. Então o que a gente fez para eliminar esse risco? Peguei um avião, fui para Porto Alegre, conversei com o promotor, expliquei a importância do acordo de leniência para uma política de investigação, porque a lei era importante, porque a constitucionalidade e ele assinou junto o acordo. Tinha uma outra dúvida institucional: era o MPE ou o MPF porque também há uma dúvida de competência, de jurisdição. Atravessei a rua, fui falar com o Ministério Público Federal, fui falar com o Procurador da República responsável, expliquei a importância do acordo de leniência e convidamos ele para assinar junto. Então MPE e MPF assinam juntos os primeiros acordos de leniência. E eu acho que essa política de chamar os MPs para assinarem juntos os acordos de leniência prevalece até hoje."
\end{abstract}

Mas a experiência do CADE e a intervenção do MP nos acordos de leniência antitruste não foram as únicas inspirações. A experiência do MPF e, especificamente dos procuradores envolvidos na Lava Jato com colaborações criminais em operações anteriores, antes da regulamentação mais importante de acordos de colaboração na Lei de Organizações Criminosas, também foi decisiva.

Somado a esses elementos, existia a múltipla incidência dos subsistemas de responsabilização, como discutido anteriormente. Em especial, a incidência da Lei de Improbidade Administrativa dava uma possibilidade de atuação do MPF na frente cível, além da criminal. Como afirma a Procuradora Regional da República Samantha Dobrowolski: ${ }^{9}$

"Os colegas se deram por competentes porque você poderia ter uma leitura que nós
não temos essa atribuição direta, ela é supletiva $[$ na $L A C]$. Mas o que foi feliz para eles
é que nos casos iniciais não tinha como incidir a Lei Anticorrupção com suas penas

$7 \mathrm{O}$ art. $3^{\circ}$ da Lei Anticorrupção, ao contrário, prevê que a responsabilização da pessoa jurídica não impede a apuração da responsabilização de seus gerentes e diretores e nada diz quando trata dos acordos de leniência.

8 BADIN, Arthur, cit.

9 DOBROWOLSKI, Samantha, cit. 
administrativas. Porém, poderia ser usada a Lei de Improbidade [Administrativa]. Então, eles tiveram essa grande sacada que o instituto tinha um aspecto procedimental formal e ele retroagiria para aplicar as penas da improbidade. Aí o Ministério Público tem uma vasta experiência na matéria, é colegitimado. (...) Os colegas mais antigos ali na Força Tarefa tinham essa bagagem, então você transpõe o mesmo raciocínio básico de colaboração e cooperação do imputado, do indiciado, réu, com o Estado do criminal para o civil com as peculiaridades de cada área. Aí eu acho que eles viram que era um mundo junto com as questões dos cartéis, viram que era um mundo de possibilidades e funcionou."

Em outras palavras, a Lei Anticorrupção não atribuía competência direta à ação do MPF. Porém, a interpretação dos procuradores é que ela não seria aplicável naquele momento, porque os ilícitos teriam ocorrido antes de 2013. Abandonar a Lei Anticorrupção, no entanto, significaria impossibilitar a celebração de acordos de leniência. Como visto no capítulo anterior, a Lei de Improbidade Administrativa, embora contenha previsões que abarcam os ilícitos que começavam a ser revelados na Lava Jato, à época proibia expressamente a transação.

A interpretação dada pelo Ministério Público Federal, naquele momento, foi audaciosa. Considerou que a Lei Anticorrupção continha dispositivos que teriam aplicação temporal diferida: as sanções não poderiam retroagir porque agravariam a situação do réu, mas os acordos de leniência, quando celebrados, levariam ao abrandamento das penalidades do conjunto de subsistemas de responsabilização da pessoa jurídica e, por essa razão, poderiam ser utilizados em prol do réu. ${ }^{10}$ Embora estivessem tratando de leis de caráter administrativo e cível, esse raciocínio sobre retroatividade se baseou, em alguma medida, na lógica do direito penal e a retroatividade de condições mais benéficas ao réu, como apontado pela entrevistada em sua fala.

Este é o contexto que possibilita o avanço do MPF. Ele combina a emergência da Operação Lava Jato, a experiência do CADE celebrar acordos com o MPF, a experiência de alguns procuradores com colaborações de pessoas físicas em âmbito criminal e a sobreposição entre Lei de Improbidade e Lei Anticorrupção.

Abre-se, então, uma possibilidade de interpretação distinta dos caminhos disponíveis aos atores. A ação de alguns indivíduos que compõem os quadros do MPF muda a construção dos acordos de leniência. Lima continua seu relato: ${ }^{11}$

\footnotetext{
"Bom, só que dentro daquela ideia da teoria dos jogos, não basta eu decidir isso [fazer acordos de leniência]. Eu tenho que comunicar as pessoas que existe essa possibilidade, senão ninguém vai saber, vai ficar só na nossa cabeça. Aí eu fiz uma entrevista
}

10 ARAS, Vladimir, cit., p. 205.

11 LIMA, Carlos F. S., cit. 
com um jornal e disse que a Lava Jato estava aberta a fazer acordos de leniência e que esses acordos envolveriam basicamente aspectos de Improbidade Administrativa, porque nós não poderíamos fazer acordos sobre multas que a competência de aplicação era da CGU. Então nós resolvemos fazer uma complementação, porque um dos aspectos não cobertos pela Lei Anticorrupção são as multas da [Lei de] Improbidade [administrativa]. Então, apesar de a Lei de Improbidade [administrativa] proibir transação, há uma divergência da interpretação, então nós dissemos que podemos fazer. Eu fiz essa entrevista, mas não bastava eu, então, decidir e comunicar, eu tinha que introduzir o dilema. Dilema era que só o primeiro, dentro daquela ideia do CADE, e está dentro da Lei Anticorrupção essa ideia também, só o primeiro se beneficiaria do acordo. Aí eu fui um pouquinho além, eu disse, na entrevista, que já existia uma empresa em conversação, eu introduzi realmente o dilema, que era a urgência da decisão das demais, quem chegasse primeiro ganharia. Este fato era o único fato não verdadeiro. Eu sei que isso é meio crítico, mas, de qualquer maneira, foi essencial. Uma semana depois já a primeira empresa aparece, por conta dessa entrevista."

Novamente, o contexto abre novas possibilidades de interpretações da regra, habilitando um curso de ação arriscado e limítrofe tomado por alguns indivíduos, com o objetivo de firmar a participação do MPF na Lei Anticorrupção e nos seus instrumentos.

O advogado Caio Farah Rodriguez, chama atenção para outro componente do contexto que possibilita a ação do MPF - o tipo de corrupção que começa a ser desvendado: ${ }^{12}$

“(...) eu acho que não é ela [a Lei Anticorrupção] que está se aplicando a nada destes casos. E por quê? Por conta do meu diagnóstico de que o que está em questão no caso da Lava Jato não é corrupção convencional. E a Lei 12.846, a Lei foi feita para combater corrupção convencional. O que é corrupção convencional? Corrupção sinalagmática, me dá contrato, eu te dou dinheiro. (...) O que estava em questão ali era outra conduta, a meu ver. Era a conduta que eu chamei em algum dos artigos, (...) $[d e]$ corrupção estrutural ou estruturante. Ela conforma, ela modela uma maneira pela qual se relacionam três conjuntos de atores, de maneira duradoura: agentes privados, agentes públicos e agentes políticos. Burocratas, políticos e empresários. E o que está em questão é você estar à mesa, é isso que está em questão, você estar na mesa do poder, do poder político, econômico. (...) Inclusive, você se dá ao luxo de ter contrato com prejuízo para não sair da mesa. Porque o objeto é a mesa e não é o contrato. E o que acontece nesta mesa? Nesta mesa acontece a definição, a formulação, deliberada ou menos deliberada, ou implícita às vezes, sobre como se dará a perpetuação ou a maximização do poder político e econômico de quem está à mesa exerce. (...) $\mathrm{O}$ essencial é a captura do futuro. São pessoas que definem o que vai acontecer com o rumo do país como um todo. (...) Diante deste tipo de situação, em que há um conflito, uma contradição tão expressiva entre estrutura social e direito estabelecido, a pergunta que cabe é: O que fazer? Sempre que você tem que fazer alguma coisa, você faz com os instrumentos que estão à

12 RODRIGUEZ, Caio F. Entrevista, São Paulo, 29 set. 2018. MP3. 
mão. Você pega os instrumentos que estão à mão: você usa um martelo para girar um parafuso. Se você tivesse uma chave de fenda, você usaria uma chave de fenda, mas você não tem, você tem um martelo. Então você tenta entrar por baixo, como se fosse um pé de cabra, por exemplo. Para mim, é isso que acontece com o Ministério Público, neste caso especificamente. Não era chave de fenda, era martelo, para tirar parafusos (...)".

O entrevistado ressalta que os instrumentos não foram pensados para o tamanho do desafio que a Lava Jato trouxe. Ainda que se mostrassem inadequados e fossem 'martelo em vez de chave de fenda para tirar parafusos', não bastava o MPF simplesmente utilizá-lo. Não bastaria um certo empreendedorismo dos procuradores ou suas interpretações. Era preciso que quem se sentasse na mesa de negociações visse o MP como parte legítima.

A adequação do Ministério Público como autoridade apta a celebrar acordos foi ressaltada por advogados entrevistados, tanto pela dupla atuação na frente penal e cível, como pelas suas características institucionais, como independência em relação aos outros Poderes, o que seria importante pelo tipo de corrupção estrutural revelada, como descrita no relato acima.

Diante desse contexto, estratégias e validações, o MPF celebra, em 2014, o primeiro acordo de leniência com a SOG, sucessora da Setal Construções, e seu grupo econômico, incluindo também prepostos, dirigentes ou acionistas.

\section{A PAVIMENTAÇ̃̃O DA ATUAÇ̃̃O DO MPF: O PRIMEIRO ACORDO}

Assinado em 22 de outubro de 2014, o primeiro acordo de leniência é feito com pouco mais de um ano de aprovação da Lei Anticorrupção, não pela autoridade prevista na Lei, mas pelo MPF. O acordo da SOG foi uma experimentação fundamental para pavimentar a operacionalização do instrumento: sua estrutura básica, suas formas de homologação e quais funções o instrumento deveria priorizar.

Para Lima, o primeiro acordo era forma de testar o uso do instrumento, porque a empresa era pequena, mas suficientemente relevante para fazer as investigações avançarem: ${ }^{13}$

\footnotetext{
"Ao vir, a Setal Gás era empresa ideal para fazer um acordo no campo da Lava Jato porque era uma empresa pequena, pouco conhecida do público e ela era uma empresa muito importante dentro do esquema porque participava desde o começo do núcleo mais duro, mais central do cartel (...). Quanto mais famosa, mais envolvida nos fatos, mais gravosas as condutas dos executivos, mais difícil de comunicar [os benefícios
}

13 LIMA, Carlos F. S., cit. 
do acordo de leniência]. Então, você foca [em fazer] um ótimo acordo e é um acordo relativamente pequeno. Nós fizemos a conjugação do acordo de leniência com improbidade, combinado com a colaboração dos executivos."

Embora não faça parte dos objetivos deste trabalho repetir cláusula por cláusula, vale entender a estrutura do acordo firmado com a SOG. ${ }^{14}$ Essa descrição permite quais são as prioridades na execução do acordo, além de antecipar aspectos que serão controvertidos entre autoridades. Os próximos parágrafos analisam a base jurídica do acordo, a definição de interesse público, o objeto, a multa e os benefícios acordados.

A base jurídica para o acordo é mais ampla do que as previsões da Lei Anticorrupção. ${ }^{15}$ Não há menção à Lei de Improbidade Administrativa, embora seja claro pelas entrevistas e pelos benefícios transacionados que ela também é base para os acordos. Por exemplo, a oferta do MPF de não propor ações cíveis em decorrência das informações prestadas ficaria prejudicada caso não abarcasse ações de Improbidade Administrativa. Tal omissão da LIA pode estar relacionada à proibição expressa da lei sobre transação de suas penalidades.

As partes definem de que forma o interesse público é atendido com a proposta. Naquele momento, não se trata de cláusula obrigatória ou regulamentada. ${ }^{16}$ Definir o interesse público neste caso importa de duas formas: primeiro, aponta qual o objetivo do acordo e, portanto, como ele pode ser satisfeito e executado pelas partes. O segundo ângulo extrapola o que é estipulado para as partes e tem

14 O chamado "termo de leniência" se divide em nove partes: base jurídica, objeto do acordo de leniência, obrigações das colaboradoras, proposta do Ministério Público Federal (que corresponderia aos benefícios decorrentes do acordo), declarações das colaboradoras e outros signatários, disposições adicionais, renúncia à garantia contra a autoincriminação e ao direito ao silêncio, rescisão e declaração de aceitação. Essa estrutura básica será, em geral, mantida nos demais acordos, com algumas adições.

15 Baseia-se na atribuição constitucional dos poderes do Ministério Público, na Lei de Proteção às Vítimas, Testemunhas e Acusados Colaboradores (Lei no 9.807/1999), nas Convenções de Palermo e Mérida, na Lei de Organizações Criminosas (Lei n ${ }^{\circ} 12.850 / 2013$ ), no Código de Processo Civil (Lei no 13.105/2016) e o Código Civil (Lei no 10.406/2002), além das previsões sobre acordo de leniência e responsabilização judicial da Lei Anticorrupção.

16 Posteriormente, em agosto de 2017, o MPF consolida suas experiências com acordos de leniência na Orientação $n^{0}$ 7/2017 da $5^{\text {a }}$ Câmara de Coordenação e Revisão que prevê que o acordo de leniência deve conter cláusulas que tratem, dentre outros assuntos, da demonstração do interesse público - sua oportunidade, efetividade e utilidade, definidos como (i) oportunidade: ser a empresa a primeira a revelar os fatos desconhecidos pela investigação, (ii) efetividade e utilidade: a contribuição real da colaboradora à investigação, por fornecimento de elementos concretos de prova, explicitados quantos e quais são os fatos ilícitos e pessoas envolvidas desconhecidos pelo MPF e quais serão os meios para obter as respectivas provas. 
um caráter comunicativo para terceiros sobre as razões para celebração daquele acordo, incluindo o Poder Judiciário e a sociedade em geral. Diz a cláusula 2a:

\begin{abstract}
"O interesse público é atendido com a presente proposta tendo em vista a necessidade de conferir efetividade à persecução criminal e civel de outras pessoas físicas e jurídicas suspeitas e ampliar e aprofundar, em todo o País, as investigações em torno de crimes contra a Administração, contra o Sistema Financeiro Nacional, crimes de lavagem de dinheiro e crimes contra a Ordem Econômica, entre outros, inclusive no que diz respeito à repercussão desses ilícitos penais na esfera cível, administrativa, tributária e disciplinar." (grifos meus)
\end{abstract}

Essa redação enfatiza a informação prestada, mas não só para identificação de outros partícipes dos ilícitos objeto do acordo ou para sua comprovação. No centro do acordo de leniência está ampliar e aprofundar outras investigações, especialmente relacionadas a outros crimes e suas repercussões civil e administrativas.

Em um acordo crucial para o MPF, não há palavras supérfluas. A definição de interesse público busca consolidar a visão do Ministério Público sobre sua competência na celebração de acordos de leniência como instrumento de produção de prova e de investigação, com ênfase em seus desdobramentos criminais, uma vez que ele é o titular por excelência das ações criminais. Outras autoridades, como CGU ou AGU, não alcançariam essa esfera.

Continuando a leitura, o objeto do acordo de leniência restringe-se às ações da SOG como prestadora de serviços técnicos de engenharia e construção civil de instalações industriais para a Petrobras, abarcando a formação de cartel e distribuição de vantagens indevidas para agentes ainda não identificados. Ainda que não se saiba todas as pessoas físicas, o acordo é bastante claro em sua delimitação. As empresas (e pessoas físicas contempladas) comprometem-se a descrever detalhadamente os ilícitos objeto do acordo e caracterizar terceiros envolvidos, juntando documentos, informações e materiais para sua comprovação. Também se obrigam a cessar envolvimento nas condutas e a cooperar com o Ministério Público e demais autoridades mencionadas, dentre outras obrigações.

É estipulado o pagamento de "multa compensatória cível", no valor de quinze milhões de reais, sendo dividida em iguais partes, metade à Petrobras e a outra metade para o Fundo Penitenciário Nacional. ${ }^{17}$ Há ressalva expressa à competência da Petrobras para pleitear ressarcimento pelos danos causados a

\footnotetext{
17 A Lei Complementar n ${ }^{\circ}$ 79/1994 estabelece fundo a ser aplicado para construção, reforma e manutenção de investimentos penitenciários, incluindo estabelecimentos penais, informação e segurança, além de programas de reinserção social, cursos, assistência. O Fundo é compartilhado com estados e municípios.
} 
ela. Não é feita referência específica a qual legislação tal multa se refere ou sua fórmula de cálculo. Além da multa, há mecanismo de recuperação de ativos que prevê que as empresas signatárias podem abater um milhão de reais da multa estipulada a cada dez milhões apreendidos, sequestrados ou perdidos em favor da União - até o limite de dez milhões de reais. ${ }^{18}$ A previsão premia os colaboradores que não só prestarem informações ou pagarem multa, mas que ajudem a identificar e recuperar ativos. Não há menção no acordo de obrigações de implementação de um programa de integridade.

Em contrapartida, o MPF promete benefícios sob sua competência, como não propor ação de natureza cível ou criminal pelos fatos e condutas revelados por meio do acordo às empresas e prepostos que decidirem colaborar.

Desde o primeiro acordo, as cláusulas expressam preocupação das partes com a articulação entre o acordo e outras instituições possivelmente envolvidas na responsabilização de pessoas jurídicas por atos de corrupção. O MPF compromete-se a zelar pela coordenação com as demais instituições de controle. Ele obriga-se a levar o acordo de leniência a outras autoridades, especialmente ao CADE e à CGU para realização de acordos semelhantes, para que a data de assinatura do instrumento com o MPF seja considerada como marcador (marker) para os critérios de anterioridade nas demais instituições. Tanto na Lei Antitruste quanto na Lei Anticorrupção só é possível celebrar leniência com o primeiro a denunciar a prática. O primeiro que decide comparecer perante as autoridades para colaborar recebe um marcador (um papel com data e hora, por exemplo) para garantir sua posição. A solução de que o acordo seja utilizado como marker depende da aquiescência das demais instituições com a validade daquele acordo.

O MPF compromete-se a participar de outros acordos feitos com CADE e CGU, desde que não conflitem com o instrumento. Em relação a outras autoridades, é prevista a proibição da divulgação ou compartilhamento do acordo, exceto com autoridades públicas aprovadas pelo MPF. É de se supor que esta última previsão tem por objetivo a preservação das investigações e da utilidade das informações.

Como dito no capítulo anterior, por existirem múltiplos sistemas de responsabilização, interessava à defesa da empresa incentivar formas de diálogo entre autoridades, como as previsões acima descrevem. A defesa da SOG, por exemplo,

18 Cf. Cláusula $7^{\mathrm{a}}, \S 1^{\mathrm{o}}$. Tal mecanismo não se repetirá em outros acordos. Neste, a cláusula $7^{\mathrm{a}}$ $\S 3^{\circ}$ prevê cronograma de pagamento somente para cinco milhões de reais (os quais não poderiam ser abatidos, conforme a previsão acima). 
poderia preocupar-se com a repercussão de acordo de leniência do MPF na esfera do CADE. A solução encontrada foi um paralelismo entre acordo com o MPF e outro acordo com o CADE. Poucos meses depois da celebração com o MPF, em março de 2015, o CADE também celebrou o acordo de leniência antitruste com a SOG e pessoas físicas. É, também, o primeiro feito pela autoridade antitruste com empresas envolvidas na Operação Lava Jato. ${ }^{19}$

Após a assinatura do acordo com os membros da Força Tarefa da Operação Lava Jato, o instrumento foi submetido à apreciação e homologação perante a $5^{\text {a }}$ Câmara de Coordenação e Revisão - Combate à Corrupção, órgão interno à estrutura do Ministério Público Federal destinado a coordenar, integrar e revisar o exercício funcional dos Procuradores. Essa é mais uma inovação. Se a lei não prevê acordos celebrados pelo MPF expressamente, tampouco prevê como seriam controlados estes acordos. A submissão à $5^{\text {a }}$ Câmara passa a ser uma prática adotada nos acordos de leniência. ${ }^{20}$ Quem revisa e como o faz é um assunto de primeira ordem em um instrumento que pressupõe discricionariedade.

Outra peculiaridade do acordo da SOG é a extensão de sua imunidade para pessoas físicas que assinam o acordo e àquelas que poderão subscrevê-lo no futuro. Para isso, é preciso mais do que a homologação interna ao MPF. O MPF, então, pleiteia a homologação do acordo em juízo criminal, nas ações criminais contra as pessoas físicas que subscrevem o acordo de leniência, adotando, novamente, um procedimento disposto na Lei de Organizações Criminosas para os acordos de colaboração das pessoas físicas. ${ }^{21}$ No caso específico da Lava Jato, a homologação é feita perante a $13^{\text {a }}$ Vara Criminal da Justiça Federal do Paraná, ocupada à época pelo juiz Sergio Fernando Moro. Como não há previsão normativa para se estender os benefícios concedidos a pessoas jurídicas para pessoas físicas na Lei Anticorrupção, além do paralelismo com a Lei de Organizações Criminosas, outra solução é pensada: aplicar por analogia a Lei do CADE que

19 SAMORA, Roberto, Cade faz $1^{\circ}$ acordo de leniência com empresas envolvidas na Lava Jato, Reuters, 2015.

20 A Lei Complementar no 74/1993 prevê em seu art. 62 o que é da competência das Câmaras de Coordenação e Revisão, mas nenhuma das ações ali descritas apontam, exatamente, para apreciação de acordos de leniência ou instrumentos negociais. O acordo de leniência da SOG foi aprovado em $1^{\circ}$ de dezembro de 2014.

$21 \mathrm{O}$ art. $4^{\circ} \S 7^{\circ}$ da Lei $n^{\circ} 12.850 / 2011$ prevê: "Realizado o acordo na forma do $\S 6^{\circ}$, o respectivo termo, acompanhado das declarações do colaborador e de cópia da investigação, será remetido ao juiz para homologação, o qual deverá verificar sua regularidade, legalidade e voluntariedade, podendo para este fim, sigilosamente, ouvir o colaborador, na presença de seu defensor." 
contém tal dispositivo. ${ }^{22}$ É uma tese ambiciosa e sem amparo específico na Lei Anticorrupção. Ainda assim, foi acatada em juízo, no acordo da SOG e nos acordos de leniência que se sucedem.

O acordo da SOG já aponta temas fundamentais à celebração de acordos de leniência pelo MPF: sua função de obtenção de informação úteis para a investigação, a articulação entre imunidades de pessoas físicas e pessoas jurídicas e, também, as tentativas de disciplinar no acordo a relação com outras autoridades. O acordo da SOG gera tentativas de inovações como a homologação perante o juízo criminal e o acordo servir como marker para outras autoridades.

Outras funções que os acordos de leniência adquiriram ainda não se manifestam. A reparação de danos ainda é pouco desenvolvida - não há especificação dos valores compensatórios. Também ainda não há preocupação com alteração do comportamento futuro da empresa por meio de obrigações de integridade.

O primeiro acordo de leniência foi crucial para testar o uso que o MPF poderia fazer do instrumento e dar seus contornos operacionais. Os próximos acordos manterão muitas das decisões tomadas no acordo da SOG, mas também aumentarão a complexidade e os dilemas da negociação. Ainda assim, esse primeiro acordo, supostamente pequeno, pavimentou o caminho para os acordos com as grandes empresas.

\section{OS GRANDES ACORDOS CONSOLIDAM A POSIC̦ÃO DO MPF}

O acordo de leniência da SOG não atraiu muita atenção. Esse cenário muda rapidamente quando empresas maiores passam a celebrar seus acordos com o MPF. São empresas de maior porte e muito mais cruciais na revelação dos ilícitos da Lava Jato. A primeira é Camargo Corrêa Construções, em agosto de 2015. No ano seguinte, em março de 2016, a Andrade Gutierrez fecha seu acordo e em dezembro é a vez da Odebrecht. O último grande acordo até 2018 feito pelo MPF é com a J\&F Investimentos, ainda em agosto de $2017 .{ }^{23}$

22 Conforme o art. $86 \S 6^{\circ}$ da Lei $n^{\circ} 12.529 / 2011$ : "Serão estendidos às empresas do mesmo grupo, de fato ou de direito, e aos seus dirigentes, administradores e empregados envolvidos na infração, os efeitos do acordo de leniência, desde que o firmem em conjunto, respeitadas as condições impostas."

23 O MPF fechou uma dezena de acordos neste período. Em ordem cronológica, os acordos homologados neste período foram firmados com: SOG Óleo e Gás, Construções e Comércio Camargo Côrrea, Carioca Christiani Engenharia S.A., Mullen Lowe Brasil Publicidade Ltda., Andrade Gutierrez Investimentos em Engenharia, Signus, Odebrecht S.A., Braskem, VRG Linhas Aéreas S.A., Rolls Royce, NM Engenharias e Construções Ltda., J\&F Inves- 
Estes casos transformam o instrumento. Eles ampliam o escopo dos acordos, abarcando mais ilícitos, aumentam a arrecadação de valores a título de antecipação de multa e alteram sua forma de cálculo. Também buscam alterar condutas das empresas, passando a contar com previsões sobre programas de compliance mais específicas. Por fim, os acordos ampliam o uso e detalham novos mecanismos de composição entre autoridades. Neste processo de tentativas e calibramento, eles mostram construções que buscam conjugar obtenção de informações, ressarcimento de danos e adoção de novas condutas pelas empresas de formas mais profundas e ambiciosas do que o acordo da SOG. Os próximos parágrafos detalham suas previsões quanto à articulação entre pessoas físicas e jurídicas, seu escopo, compartilhamento de provas com outras autoridades, valores de ressarcimento (incluindo sua distribuição e compensação) e obrigações de integridade.

A Camargo Côrrea foi pioneira dentre as grandes construtoras. ${ }^{24}$ À época, a Força Tarefa da Lava Jato declarou em comunicado oficial: "Esse acordo estabelece um novo paradigma no direito brasileiro." ${ }^{25}$ Inspirada em soluções feitas pela empresa Siemens para remediar seus atos de corrupção, ${ }^{26}$ a Camargo Corrêa

timentos S.A.. Vide lista completa divulgada pelo MPF em http://www.mpf.mp.br/atuacao-tematica/ccr5/coordenacao/colaboracoes-premiadas-e-acordos-de-leniencia/colaboracoes-premiadas-e-acordos-de-leniencia. Acesso em: 25 jan. 2019.

24 Paralelamente, o grupo celebra acordo de leniência plus com o CADE confessando sua participação no cartel de licitações da Petrobras e oferecendo evidências em relação ao cartel relativo às obras de empresas de energia Eletrobras e Eletronuclear em projetos como Angra 3, vide Processo Administrativo CADE nº. 08700.007351/2015-51. Leniência plus é um programa no CADE introduzido em 2015 no qual a empresa que trouxer evidências sobre novo caso de cartel recebe redução de até um terço da penalidade aplicável no caso em que já era investigada e imunidade no novo caso que revelar. Ver Guia Programa de Leniência Antitruste do CADE do Conselho Administrativo de Defesa da Concorrência, maio de 2016, disponível em http://www.cade.gov.br/acesso-a-informacao/publicacoes-institucionais/ guias_do_Cade/guia_programa-de-leniencia-do-cade-final.pdf. Acesso em: 25 jan. 2019.

25 O comunicado continua: "obediente ao sistema implantado pela legislação contra a corrupção, contra os ilícitos econômicos e lavagem de dinheiro, e alinha-se à prática dos melhores sistemas jurídicos do mundo". CONJUR, Camargo Corrêa firma acordo com MPF e irá devolver R \$ 700 milhões.

26 O caso Siemens é um dos mais importantes e conhecidos de suborno transnacional. À época, em 2008, o caso foi descrito por autoridades americanas como "sem precedentes em escala e alcance geográfico, envolvendo mais de 1.4 bilhões de dólares para agentes públicos na Ásia, África, Europa, Oriente Médio e nas Américas". Além de fechar um acordo bilionário com autoridades europeias e americanas, a empresa ficou conhecida por implementar um programa de integridade extenso, incluindo um comitê de auditoria independente, além de quatro forças tarefas (investigação, remediação, compliance e comunicação). Ver HEALY, Paul; PETKOSKI, Djordjija. Fighting Corruption at Siemens. 2012. Disponível em: https:// www.hbs.edu/faculty/Pages/item.aspx?num=41655. Acesso em: 28 jan. 2019. 
fez um programa de colaboração interno, no qual as pessoas físicas eram convidadas a detalhar ilícitos que participaram, bem como a apresentar evidências à empresa, em troca de alguns benefícios. Segundo Badin, a conexão entre pessoa física e pessoa jurídica era fundamental para o deslinde do caso: ${ }^{27}$

\begin{abstract}
"A Camargo Corrêa foi a primeira empresa que procurou o CADE, a CGU, e o próprio MPF ainda em novembro de 2014 para negociar um acordo que envolvesse as pessoas físicas, seus executivos e a empresa. $\mathrm{O}$ que percebemos é que não tem como separar pessoa física da empresa. A empresa depende da colaboração das pessoas físicas. E a colaboração das pessoas físicas depende muito das investigações internas que são feitas pelas empresas que é onde está a documentação e a comprovação. (...) É por isso que, também na esteira do caso da Siemens, formatamos um programa de leniência interno que demos o nome de Programa Interno de Incentivo à Colaboração. (...) Basicamente dizer: 'funcionários, se alguém souber de alguma irregularidade e se apresentar e trouxer os documentos e confessar as práticas, a empresa vai dar todo o apoio jurídico, pagar a defesa, investir todos os esforços para ajudar um acordo de colaboração, arcar com as consequências cíveis, pecuniárias que possam decorrer desta colaboração, assegurar uma indenização em caso de perda de capacidade laboral, venham, vai custar para a empresa, mas venham'. E por quê? Porque para a empresa, por mais apuradas que sejam as técnicas de investigação interna, é muito difícil, é quase achar uma agulha no palheiro, porque a empresa tem um faturamento naquele ano de seis bilhões de reais. A quantidade de contratos, fornecedores, é uma coisa assim que o que a gente não tem ideia do tamanho (...). Então esses programas se provaram muito [positivos] para que as pessoas saíssem da inércia e do medo de não colaborar, de o colaborador perder o emprego e ainda ter um problema criminal. Esses programas eu acho que serviam para tirar tudo que tinha nas gavetas. Por outro lado, é o seguinte: para a empresa, o pior dos mundos, uma expressão que eu usei em umas entrevistas: 'é melhor um fim horroroso do que um horror sem fim'. É melhor enfrentar todos os problemas de uma vez do que ficar convivendo com uma sucessão de crises (...). [Para] limpar todas as gavetas, precisa ter esse esforço de incentivar os colaboradores, as pessoas de colaborarem."
\end{abstract}

Se a empresa decide colaborar, ela precisa enfrentar também a responsabilidade dos indivíduos como forma de obter informações completas e corroboradas. Na descrição, a empresa é um centro de informações, mas, por seu tamanho e seu volume, depende de indivíduos para identificar práticas ilícitas. Para esta estratégia, o Ministério Público é negociador ideal, porque pode atuar na responsabilização criminal do indivíduo e na responsabilidade cível da empresa. ${ }^{28}$

\title{
27 BADIN, Arthur, cit.
}

28 A possibilidade de dupla atuação do MP é reforçada por Dobrowolski: “(...) a repercussão penal sempre tem a interação entre a necessidade de se fazer a leniência da empresa com a colaboração de algumas pessoas físicas, sejam elas acionistas, sócios, dirigentes ou aqueles que vão corroborar com aquilo que diz a empresa. Quer dizer, eles vão ter um interesse em corroborar no crime, e aí que o protagonismo do MP, mas seria do MP muito mais do que a polícia porque tem a contraface da improbidade, porque aí já resolve essas duas esferas." 
A ligação entre colaboração de pessoa física e pessoa jurídica também está relacionada à estrutura societária brasileira, como reforçado por Rodriguez: ${ }^{29}$

“[ $L A C]$ É a cópia de uma legislação estrangeira - responsabilidade objetiva - mas
como é a estrutura de capital nos EUA? Ela é pulverizada. Aqui, em razão da estrutu-
ra de capital, não pode ser assim. Porque se você fizer isso, de repente, você não tem
controlador mais na empresa. (...) Como há um controlador que em geral é uma pessoa
física, essa pessoa não vai deixar que seja feito um acordo de leniência em que ela
seja jogada under the bus. É por isso também que, do ponto de vista prático, é melhor
fazer com o MPF. Como ele tem as duas competências, você já fala tudo para uma
autoridade só. Segundo os dois aspectos relevantes, o civil e o criminal. E é por isso
que nos EUA você também pode ter um órgão que faz uma parte, por que quem liga
para as pessoas físicas? Ninguém liga para as pessoas físicas.”

No acordo da Camargo Corrêa, assim como nos demais, há distinção entre pessoas físicas que celebram acordos de colaboração individuais e, portanto, têm os termos de sua imunidade penal negociada em separado e pessoas físicas que aderem ao acordo de leniência, sendo o primeiro tipo de acordo preponderante. A lógica seria preservar o processo e negociação criminal com pessoas físicas que tiveram participação substantiva nos ilícitos relatados, enquanto estende a imunidade penal do acordo de leniência apenas àquelas que tiveram papel coadjuvante, mas que, ainda assim, auxiliaram a empresa a descrever infrações e desvendar evidências.

Ao longo dos próximos acordos, a imunidade estendida a pessoas físicas pelo acordo de leniência fica cada vez mais criteriosa, dando preferência a acordos de colaboração individual, de forma que participem dos benefícios de acordos de leniência apenas agentes que não tiveram preponderância nos ilícitos. ${ }^{30}$

A articulação entre pessoas físicas e jurídica torna-se ainda mais relevante se o escopo do acordo é amplo. Se for limitado a alguns contratos isolados, por exemplo, é possível que a empresa conseguisse corroborar as informações sem precisar de indivíduos. Quanto mais amplo o escopo do acordo, a localização da fraude ou o caminho de pagamentos ilícitos podem ser mais complexos, se a empresa estiver envolvida em múltiplos ilícitos, como as empresas colaboradoras da Lava Jato confessaram estar.

O acordo da Camargo Côrrea tem escopo mais abrangente do que o da SOG. Estão abarcadas atividades das pessoas jurídicas e pessoas físicas aderentes ao acordo investigadas nos procedimentos da Lava Jato, bem como na VALEC/

30 RODRIGUEZ, Caio F, cit. 
Ferrovia Norte-Sul. ${ }^{31}$ Os ilícitos abarcados vão além de serviços prestados à Petrobras - tal qual definido no acordo da SOG - e estão relacionados a serviços de construção civil e EPC (engineering, procurement \& construction) em "fraudes em licitações de órgãos públicos federais, empresas públicas e sociedades de economia mista controladas pela União Federal, dentre outros crimes".

Em verdade, a cada acordo firmado, o MPF amplia seu escopo. Até o ponto no qual eles se tornam tão abrangentes que englobam todos os ilícitos relevantes já cometidos pela empresa, como é o caso da Odebrecht. Essa expansão é proposital e busca resolver os problemas enfrentados pelas empresas em um único instrumento - para 'limpar as gavetas', na expressão de um entrevistado.

Também, a expansão do escopo em uma mesma investigação é forma de cumprir o requisito da Lei Anticorrupção que autoriza acordo apenas com a primeira empresa que confessa a prática ilegal, no qual um acordo de leniência só se justificaria se fatos ainda não revelados ou sabidos pela autoridade forem trazidos pelas pessoas jurídicas sobre novos ilícitos.

Porém, a expansão do escopo não decorre apenas do requisito legal aos acordos de leniência ou da estratégia das empresas. É também parte da estratégia da Lava Jato: ${ }^{32}$

\footnotetext{
"Nós definimos [o objeto do acordo de leniência] basicamente fora da Petrobras, porque daí começam a vir Eletronuclear e outras empresas estatais. (...) Esse conceito é, assim, bastante movediço, então era de utilidade que a gente tivesse uma certa flexibilidade, porque se nós ficássemos só com a Setal [SOG], nós teríamos provado o núcleo básico só, mas a partir do momento em que permitimos esse aumento, nós fomos espraiando a Lava Jato, por exemplo, o que existe da Lava Jato no RJ basicamente é uma derivação desse acordo sobre a Eletronuclear, que foi tirado daqui e foi mandado pro Rio. E a partir daí, o Rio espraiou, inclusive para o governo estadual. Temos alguns pilares da Lava Jato, um deles é o que eu chamo de Blietzkrieg, que é ampliar ao máximo o campo de incidência da operação em medidas, operações subsequentes, uma atrás da outra, impedindo a reorganização das organizações criminosas. E a gente foi avançando. Então você pega a Eletronuclear, você pega Caixa Econômica, você vai evoluindo assim."
}

A ampliação do escopo dos acordos de leniência é uma forma de expandir a competência do MPF e das investigações, mas não é uma estratégia sem riscos. Ela aumenta potenciais problemas de compatibilização com outras instituições

31 O caso se refere à existência de cartel e pagamento de propina para executar obras da Ferrovia Norte-Sul (entre Anápolis em Goiás e Palmas, no Tocantins) em contratos assinados com a VALEC Engenharia, Construções e Ferrovias S.A., empresa estatal ligada ao Ministério dos Transportes.

32 LIMA, Carlos F. S., cit. 
de controle, incluindo com outros entes federativos, como Estados e Municípios, a depender do que é relatado.

A definição do escopo de um acordo de leniência, vale dizer, não é imutável. $\mathrm{Na}$ verdade, nas diversas facetas da Lava Jato, ela variou. Apenas como exemplo desta plasticidade do escopo dos acordos, é possível contrastar as definições dos acordos entre MPF e CADE. Enquanto o MPF definiu como escopo dos acordos de forma abrangente, o CADE, a partir da definição de mercado relevante, subdividiu o mercado em cada contrato público firmado (por exemplo, contratos com a Petrobras, Angra 3, metrô). ${ }^{33}$ Isso resultou em uma fragmentação maior do escopo dos acordos realizados em âmbito de responsabilização antitruste. Hipoteticamente, seria possível argumentar que o cartel que operava nestas obras públicas era o mesmo. A indicação de diferentes ganhadores e perdedores de cada um apenas refletiria a divisão de mercado acertada por um núcleo duro de empresas, com a eventual participação de empresas menores. Esse não foi o caminho escolhido pela autoridade. O exemplo do CADE nos ajuda a desnaturalizar as definições do MPF como as únicas possíveis.

Retornando às funções dos acordos de leniência na Lei Anticorrupção, o acordo da Camargo Corrêa também inova na função de reparação de danos. $\mathrm{O}$ acordo apresenta mudanças nas destinações dos recursos: são disponibilizados mais recursos aos entes lesados, mas sob definição do MPF. Muda-se a destinação de parte dos recursos: do fundo penitenciário aos órgãos federais encarregados de investigação e punição dos ilícitos previstos na Lei de Lavagem de Dinheiro. ${ }^{34}$

As colaboradoras concordam com o pagamento de multa compensatória de setecentos milhões de reais, ressalvada a possibilidade de apurar outros danos: $90 \%$ seria destinado às empresas lesadas e $10 \%$, aos órgãos federais encarregados

33 O guia do CADE para Análise de Atos de Concentração Horizontal define mercado relevante "como o processo de identificação do conjunto de agentes econômicos que efetivamente regem e limitam as decisões referentes a estratégias de preços, quantidades, qualidade (entre outras) da empresa resultante da operação." (p. 12).

34 Trata-se de uma previsão da Lei de Lavagem de Dinheiro, a Lei no 9.613 de 1998. De acordo com o art. $7^{\circ}$ : "São efeitos da condenação, além dos previstos no Código Penal: (...) I - a perda, em favor da União, dos bens, direitos e valores objeto de crime previsto nesta Lei, ressalvado o direito do lesado ou de terceiro de boa-fé; $\S 1^{\circ}$ A União e os Estados, no âmbito de suas competências, regulamentarão a forma de destinação dos bens, direitos e valores cuja perda houver sido declarada, assegurada, quanto aos processos de competência da Justiça Federal, a sua utilização pelos órgãos federais encarregados da prevenção, do combate, da ação penal e do julgamento dos crimes previstos nesta Lei, e, quanto aos processos de competência da Justiça Estadual, a preferência dos órgãos locais com idêntica função.” 
de prevenir, combater e propor ação penal. $\mathrm{O}$ valor é dividido entre Operação Lava Jato e VALEC/Ferrovia Norte-Sul em Goiás, cabendo à última pouco mais de $10 \%$ do total. Para os entes lesados, a proporção de reparação que cada um teria direito seria calculada pelo MPF.

O acordo da Camargo Corrêa traz nova obrigação que se torna constante para os demais acordos: o compromisso de a empresa adotar programa de integridade, no caso específico, conforme padronização ISO com apresentação de plano de implementação ao MPF. Estas previsões atribuem uma nova função aos acordos. Os acordos não tratam apenas de ampliar investigações criminais e cíveis ou antecipar a reparação de danos, mas também de garantir uma mudança substantiva na cultura corporativa das empresas, para seus negócios futuros. Isto significa que a atuação do MPF deve incluir formas de avaliação, não só das provas ou dos valores desembolsados pelas empresas, mas também do cumprimento de novas obrigações de compliance e transformações da governança da empresa.

Esta nova função gera dilemas próprios. Uma vez que programas de integridade são obrigações impostas por outras autoridades, por exemplo, para redução de multas de TCCs no CADE e, também, mais adiante, para a CGU, resta a pergunta sobre a compatibilização entre os parâmetros adotados para cada uma delas. Esse pode ser um problema na interação entre atores: compatibilizar quando as autoridades se darão por satisfeitas com o programa de compliance, como farão suas avaliações e quais os padrões sinalizados aos agentes privados (mais ou menos profundos, com maior ou menor monitoramento). ${ }^{35}$

No acordo de leniência da Camargo Côrrea não há inovações dentre as obrigações do MPF. Há previsão de que o acordo sirva como marker e, como mecanismo de fomento à composição entre autoridades, permanece igual ao da SOG, a obrigação de levar o acordo de leniência às demais autoridades. ${ }^{36}$

No início de 2016, foi a vez da Andrade Gutierrez celebrar acordo de leniência. Mantém-se a extensão a pessoas físicas. A partir da lógica de expansão do

35 MATTIUZZO, Marcela, Concorrência e Corrupção - Programas de Compliance no Debate Jurídico-Institucional Brasileiro, Revista de Defesa da Concorrência, v. 5, n. 1, p. 5-20, 2017.

36 Há inclusão da seguinte declaração pelo MPF “por força do que é declarado no presente termo, o Ministério Público Federal, no âmbito de suas atribuições, considera suficientemente satisfeitas as repercussões cíveis desses ilícitos penais praticados em benefício de Construções e Comércio Camargo Corrêa S.A.” (cláusula $8^{\mathrm{a}}, \S^{\circ}$ ). O dispositivo parece tentar resguardar a empresa de novas ações de improbidade ou outras formas de reparação de danos, ao menos no âmbito do Ministério Público Federal. 
objeto dos acordos de leniência, como já narrada, estão inclusos nesse instrumento ilícitos relativos a empreendimentos da VALEC/Ferrovia de Integração Oeste Leste (FIOL), ${ }^{37}$ assim como outras investigações que sejam instauradas em decorrência dos fatos trazidos pela colaboradora.

Em relação a reparação de danos, a empresa se compromete a pagar multa cível (em seu nome e de seus prepostos) no valor de um bilhão de reais, sendo $10 \%$ destinado a autoridades investigadoras, nos termos da Lei de Lavagem de Dinheiro, e 90\% às empresas lesadas, segundo proporção dos danos estipulada pelo MPF, em doze parcelas. ${ }^{38}$ Assim como o acordo da Camargo Côrrea, há previsão da repartição de parcela dos recursos destinada a investigadores entre investigações da Lava Jato e demais investigações reveladas no acordo. A operacionalização da repartição será determinada por meio de decisão conjunta dos Ministérios Públicos envolvidos.

Há inovação quanto a mecanismos de compensação no acordo de leniência. A introdução de formas de compensação de multa são uma forma de tentar garantir que a empresa não pagará além daquilo estipulado no acordo em razão da ação de outras autoridades. Busca-se antecipar este movimento, prevendo no acordo de que a multa estipulada pode ser compensada em favor da colaboradora em eventual ação de objeto extrapenal ou processo administrativo, a critério da respectiva instituição competente, excluídos apenas assuntos tributários.

$\mathrm{O}$ acordo da Andrade Gutierrez amplia alguns mecanismos de composição entre autoridades eventualmente competentes. Além do compromisso de levar o acordo como marker, há obrigação de "gestionar junto a promotores naturais, nos casos de atribuição da Procuradoria Geral da República, a adesão a este acordo de leniência". Neste caso, busca-se ampliar a adesão a procuradores do MPF. Como se verá no acordo da Odebrecht, o mecanismo de adesão de outros Ministérios Públicos ao acordo se torna cada vez mais procedimentalizado e regrado. Assim como no acordo da Camargo Côrrea, a Andrade Gutierrez se compromete a adotar programas de compliance.

Em dezembro de 2016, a Odebrecht e a Braskem ${ }^{39}$ assinaram acordos de leniência simultâneo com autoridades brasileiras, americanas e suíças. Também foram celebrados acordos de colaboração com setenta e oito de seus executivos. Não faltaram superlativos para descrever o caso. O Departamento de Justiça

\footnotetext{
37 Relacionada à existência de cartel e pagamento de propinas em obras da ferrovia que interliga Ilhéus (Bahia) a Figueirópolis (Tocantins).

38 Corrigidas pela SELIC.

39 Ambas integrantes do mesmo grupo econômico.
} 
americano classificou os acordos como "a maior resolução global de caso de propina transnacional" por violação ao FCPA. ${ }^{40}$ No Brasil, os acordos ficaram conhecidos como a "delação do fim do mundo" pelo seu alcance nacional e internacional ${ }^{41}$ e pelas implicações trazidas ao sistema político, com denúncia a diversos de seus membros. ${ }^{42}$

Os acordos anteriores da Camargo Côrrea e Andrade Gutierrez já sinalizavam a expansão das funções dos acordos de leniência, por exemplo, de obrigações de compliance. Porém, o acordo de leniência da Odebrecht é explícito em consolidá-lo como instrumento que serve à múltiplas funções. Há expansão da definição de interesse público para fins do acordo em relação aos acordos anteriores. Ele mantém as previsões sobre efetividade e ampliação das investigações, mas agora o interesse público é também:

\begin{abstract}
“(...) (ii) preservar a própria existência da empresa e a continuidade de suas atividades, o que, apesar dos ilícitos confessados, encontra justificativa em obter os valores necessários à reparação dos ilícitos perpetrados; (iii) assegurar a adequação e efetividade das práticas de integridade da empresa, prevenindo a ocorrência de ilícitos e privilegiando em grau máximo a ética e transparência na condução de seus negócios; e (iv) estimular que a colaboradora entabule negociações e conclua acordo em outras jurisdições, que porventura possam ter interesse em acordos semelhantes, para o fim de ser promovida a expansão das investigações de corrupção no Brasil e no exterior."
\end{abstract}

Descobrir ilícitos e investigá-los em âmbito nacional, com base nas evidências apresentadas já não é mais a única função do acordo. As partes signatárias concordam que ele serve também expandir investigações para outras jurisdições, preservar a empresa o quanto necessário à reparação de danos e prevenir novos ilícitos por meio de programas de integridade.

40 Comunicado à imprensa disponível em https://www.justice.gov/opa/pr/odebrecht-and-braskem -plead-guilty-and-agree-pay-least-35-billion-global-penalties-resolve. Último acesso em: 29 jan. 2019.

41 A empresa admitiu ter pago propinas superando 788 milhões de dólares em dez países da América Latina, bem como Angola e Moçambique. Para mais informações sobre investigações fora do Brasil, ver PIMENTA, Raquel de Mattos; GREENE, Catherine, The Lava Jato Corruption Scandal: Comparing the Responses of Peru and Mexico, New York: Center on Global Economic Governance at the School of International and Public Affairs, Columbia University, 2018.

42 Ficou conhecida como a "Lista de Janot" a relação de inquéritos apresentados pelo então Procurador-Geral da República ao STF envolvendo políticos supostamente envolvidos nos ilícitos narrados pela empresa em seus instrumentos. MATTOSO, Camila; CASADO, Letícia, Cinco ministros de Temer, Aécio, Lula e Dilma estão na lista de Janot, Folha de S.Paulo, 2017. 
Em relação à primeira função, o escopo do acordo continua a trajetória de expansão do escopo de informações que devem ser prestadas. Ele inclui atos relacionados à investigação na Lava Jato que possam caracterizar ilícitos, incluindo, agora, ilícitos eleitorais e crimes de qualquer natureza. Também estão abarcados ilícitos que não sejam conexos ou correlatos às investigações da Lava Jato, mas descobertos no âmbito de investigações internas, desde que praticados no âmbito dos fatos descritos pelas colaboradoras. A empresa expressamente afirma que reportará todos fatos apurados com a intenção de ampliar na máxima extensão possível a sua proteção e a utilidade do acordo. Ao passo que mais amplas, as exigências das informações prestadas pela empresa parecem também se tornar mais específicas, como listar doações eleitorais ou beneficiários de pagamentos de vantagens indevidas. ${ }^{43}$

Em relação ao ressarcimento de danos, há também novas configurações. No acordo de leniência global, a empresa concorda em pagar 3,8 bilhões de reais ou cerca de 2,6 bilhões de dólares. Tal valor foi estipulado, inicialmente, e, depois, reajustado a partir da estimativa da habilidade da empresa de pagar. A chamada ability to pay é sujeita à verificação da veracidade das declarações prestadas, inclusive por meio da contratação de assessoria financeira arcada pela empresa. Este condicionamento do pagamento à preservação da empresa é um método novo em relação aos acordos anteriores e, provavelmente, deriva da experiência americana, uma vez que o acordo da Odebrecht é firmado em conjunto com as autoridades americanas.

São descontadas parcelas destinadas às autoridades americanas e suíças (10\% a cada uma). Do restante, $97.5 \%$ são destinados "para fins de ressarcimento dos danos materiais e imateriais" de entes públicos lesados e $2.5 \%$ conforme a previsão da Lei de Lavagem de Dinheiro. O acordo da Odebrecht, então, prevê maiores percentuais a entes lesados do que os anteriores. Assim como no acordo da Andrade Gutierrez, é prevista a possibilidade de compensação de valores do total pago, em razão de outras decisões judiciais, de bloqueio cautelar ou, ainda, de transação decorrente de fatos abrangido pelo acordo.

Também parecem se tornar mais específicas obrigações para alterar a conduta da empresa. O MPF pode demandar treinamento (curso, seminário) de pessoas físicas para reabilitação ético-profissional. Destaca-se, também, a realização de monitoramento independente para implementar programas de integridade e

43 Não é possível saber, pelos documentos públicos, se as demais empresas já prestavam informações com o mesmo nível de detalhamento. É possível que sim. No entanto, no acordo da Odebrecht este detalhamento sobre um escopo tão amplo se torna explícito. 
supervisionar a implementação do acordo. Trata-se de um modelo que se tornou comum em alguns acordos americanos, ${ }^{44}$ mas é inovador no Brasil e não possui previsão legal expressa. Isto é, por meio de acordo de leniência, a empresa concorda em ser acompanhada por pessoas escolhidas pelas autoridades para garantir a transformação de sua cultura e prática empresarial. Até o final de 2018, foi uma estipulação única nos acordos de leniência celebrados, o que gera a dúvida sobre a proporcionalidade do uso de monitores independentes apenas em um caso, por mais importante que seja. Parece não ser uma ferramenta disponível (além do contexto de acordo conjunto celebrado com a autoridade americana) e, tampouco, prever em quais situações esta medida deve ser implementada.

Como comentado, a definição fluida dos contornos do objeto do acordo gera desafios. Uma delas é a dúvida de competência para analisar os fatos e evidências apresentadas que não sejam relacionadas à Lava Jato. Os entrevistados relataram preocupação não só com a coordenação das demais instituições de controle externo, mas dentro do Ministério Público Federal e outros Ministérios Públicos. Isto porque a composição do próprio Ministério Público não é óbvia, pela estrutura constitucional que garante independência de atuação, entre membros individuais e entre braços distintos do Ministério Público. A independência funcional pode criar incentivos para descentralização e mais atores buscarem informações e promoverem investigações de combate à corrupção, mas aumenta a complexidade da definição do acordo de leniência.

Nesta realidade, os mecanismos de adesão que já surgiram em outros acordos, tornam-se uma iniciativa importante para garantir certa uniformidade de atuação. Aqueles que aderem ao acordo possuem, em troca, acesso às informações. No acordo da Odebrecht, são previstos procedimentos para que sejam dadas informações parciais a membro do MP competente e, diante da sua eventual adesão ao acordo de leniência, informações completas. O acordo também estipula formas de repartir os valores entre entes lesados de níveis federativos distintos.

As obrigações do MPF se dividem entre aquelas assumidas no âmbito da Lava Jato e para os demais membros do Ministério Público que aderirem ao acordo. São, também, mais específicas. A obrigação de levar o acordo a outras autoridades não se restringe a que o acordo seja considerado como marker, mas também "evitar o ressarcimento em duplicidade no tocante ao valor pago por meio do acordo". Esse tipo de previsão demonstra a preocupação das empresas com sua exposição a penalização por outras autoridades.

44 ARLEN, Jennifer; KAHAN, Marcel, Corporate Governance Regulation through Nonprosecution, University of Chicago Law Review, v. 84, p. 323-388, 2017. 
O MP, ainda, se compromete a emitir certidões atestando a extensão da colaboração, o grau de relevância dos fatos apresentados, dentre outros elementos, seja para celebração de acordos com demais autoridades, nacionais, subnacionais e estrangeiras, seja para celebração ou manutenção de contratos com terceiros, incluindo instituições financeiras, seguradoras ou adquirentes de ativos, respeitado o dever de sigilo quanto às informações prestadas. Também, se obriga a envidar esforços para que se retire restrições cadastrais, desbloqueie bens no âmbito das ações propostas pelo MP e busque a retirada de medidas cautelares propostas por outros colegitimados, inclusive perante os Tribunais de Contas.

Há também mecanismo para buscar coesão em ações civis públicas e de Improbidade Administrativa. Naquelas já propostas em relação ao grupo econômico, o MPF e os MPs que aderirem ao acordo se comprometem a postular, sejam eles autores ou não, a suspensão do processo ou o reconhecimento de efeito meramente declaratório sem aplicações de novas sanções. Novamente, são soluções encontradas no caso concreto, uma vez que não há previsão na lei sobre o impacto do acordo sobre as demais ações propostas fora do escopo da Lei Anticorrupção.

Busca-se atentar também para ações que podem ser propostas pelos entes lesados. O MPF se compromete a postular que qualquer ente lesado que vise ressarcimento pelos fatos abrangidos pelo acordo compensem os valores pagos no acordo do débito da colaboradora. E, ainda, concedam o chamado 'benefício de ordem' em face de outras pessoas jurídicas que sejam solidárias ao mesmo débito. Ou seja, que as autoridades busquem cobrar o débito de outros, não colaboradores, antes de alcançar o patrimônio da colaboradora.

Claro que a linguagem de todos os acordos - como "empreender gestões, gestionar" - indicam que proteção e defesa do acordo dos Ministérios Públicos perante terceiros, incluindo outras instituições de controle e entidades lesadas, é uma obrigação que não garante o resultado. O que pode significar, no limite, que as cláusulas não limitam a exposição de empresas a outros procedimentos de responsabilização ou sanções.

Essa exposição cria-se um diálogo constante entre MPF e empresa, evidência do que se chamou de "casamento entre empresa e estado". ${ }^{45}$ Nas palavras de Lima: ${ }^{46}$

45 PIMENTA, Guilherme, Acordo de leniência: um casamento entre empresa e Estado. Jota Info.

46 LIMA, Carlos F. S., cit. 


\begin{abstract}
"A fase pré da negociação, tudo é muito importante, mas a fase pós é extremamente trabalhosa, é casamento, você fica ali tendo que lidar às vezes semanalmente com demandas da empresa. 'O TCU está bloqueando minha conta, o que vocês podem fazer para explicar para o TCU ou CGU?'; 'Nós estamos em negociação com a CGU'; 'Precisamos de uma certidão para créditos bancários'. O pós-negociação é muito complicado, então quanto mais você fechar tudo no acordo, e é impossível você reunir todas as oportunidades que podem surgir, melhor, então a fase pré é muito importante para você fazer um acordo bem feito (...)".
\end{abstract}

Regula ainda algumas formas de governança do grupo, incluindo como será preservada a capacidade financeira da empresa - sendo que a empresa deve informar ao MPF fatos ou atos relevantes, por analogia àqueles assim considerados pela Lei das Sociedades Anônimas (Lei 6.404/1976) que possam afetar significativamente sua capacidade financeira e os compromissos assumidos. Aqui há outro exemplo de mobilização de outro conjunto normativo (Lei das S.A.) para construção dos acordos.

Os grandes acordos - pela extensão do que foi relatado e a complexidade que ensejam para autoridades e agentes privados - foram inaugurados pelas empreiteiras, mas não acabaram nelas. O acordo da J\&F Investimentos, holding do grupo econômico da JBS, é o último grande acordo celebrado pelo MPF, em esforço conjunto entre a Lava Jato e a Força Tarefa Greenfield. ${ }^{47}$

Assim como o acordo de leniência da Odebrecht, o acordo assinado pela J\&F se define interesse público de forma abrangente, muito além de dar efetividade às investigações. Seu escopo é, também, o mais amplo possível, incluindo ilícitos "genericamente passíveis de repressão pelo Ministério Público" e outros que resultem de fatos descobertos em investigação interna, incluindo no futuro. ${ }^{48}$ Parece ser a previsão mais abrangente do escopo dos acordos de leniência.

A articulação entre pessoa física e pessoa jurídica mantém-se importante, agora não só para a obtenção de informação ou articulação com investigações criminais. Quem apresenta garantia ao acordo são os próprios controladores da empresa. ${ }^{49}$ Também é previsto que o acordo pode ser integralmente rescindido

47 A Força Tarefa Greenfield envolve ilícitos praticados contra fundos de pensão, sobretudo FUCEF, Petros, PREVI, bem como Fundo de Garantia do Tempo de Serviço (FGTS) e Caixa Econômica Federal. Ela é composta de seis operações: Greenfield, Recomeço, Conclave, Sépsis, Cui Bono, Tesouro Perdi, Patmo e Fundo Perdi.

48 Na redação do acordo: "mesmo que não conexas ou correlatas os fatos ou condutas em investigação do Ministério Público Federal."

49 Cf. a cláusula 31 do Acordo: "Os Intervenientes Garantidores Joesley Mendonça Batista e Wesley Mendonça Batista assumem, na qualidade de fiadores e nos termos dos artigos 818 e 827 do Código Civil, as obrigações pecuniárias da Colaboradora, nos termos e condições previstos neste Acordo de Leniência." 
caso o acordo de colaboração firmado por executivos da empresa seja anulado pelo STF. Ou seja, o destino do acordo de leniência passa a ser firmemente ligado ao destino das pessoas físicas de forma que não estava prevista em acordos anteriores.

Em relação às obrigações de ressarcimento assumidas pela $\mathrm{J} \& \mathrm{~F}$, pactua-se o pagamento de multa de 10,3 bilhões de reais, a serem pagas em 25 anos. Além do valor expressivo, destacam-se diversos mecanismos de abatimento da multa por sanções impostas por outras autoridades ou entidades lesadas. Além de compensações já vistas em outros acordos, agora multas a pessoas físicas, incluídas em acordos de colaboração, podem ser abatidas do valor de ressarcimento da empresa. Um novo elo entre responsabilidade da pessoa física e pessoa jurídica.

Ainda, diferente dos demais acordos, não há destinação de percentual a entes lesados, mas valores já pré-determinados. A destinação do recurso é também bastante distinta. Não há uso da previsão da Lei de Lavagem de Dinheiro quanto o uso de recursos para autoridades de investigação e punição, possivelmente por interpretação do STF. Em inovação, 2,3 bilhões de reais são destinados para execução de projetos sociais em áreas temáticas diversas, algumas sem relação com os ilícitos descritos pela pessoa jurídica. ${ }^{50}$

Para dar conta dessa nova previsão, é elaborada uma estrutura de governança dos recursos. A execução de projetos sociais é objeto de auditoria independente específica que tem como objeto o uso correto dos recursos e a avaliação do impacto de cada projeto. Tais relatórios devem ser entregues anualmente ao MPF para fins de controle. Há ainda obrigação de publicidade ativa dos projetos sociais feitos, vinculando-os ao acordo com o MPF. Além de avaliar as informações, o ressarcimento e o programa de integridade, caberia ao MPF também acompanhar a gestão e o uso de recursos em projetos sociais.

Pela complexidade criada por um acordo tão amplo, com valores não só substantivos, mas também com destinação distinta (projetos sociais), o acordo prevê a criação de um Comitê de Supervisão Independente que informará ao Ministério Público relatórios sobre as obrigações assumidas no acordo de leniência, incluindo investigações e monitoramento da implementação das demais exigências. O comitê é, possivelmente, uma ampliação da figura do monitor independente, em uma estrutura de governança corporativa distinta.

50 Por exemplo, fomento a programas de alfabetização na primeira infância, combate a doenças tropicais, construção de abrigos e formação de rede de apoio para moradores de rua, inclusão digital e formação de rede de dados wi-fi em comunidades carentes. 
O MPF, ainda, se obriga a empreender diálogo ativo com autoridades nacionais e com autoridades estrangeiras, para que o acordo de leniência, além de ser considerado como marker evite o pagamento em duplicidade a título de ressarcimento. $\mathrm{O}$ instrumento ainda possui previsões detalhadas para compartilhamento de provas com outros Ministérios Públicos. Ao final de 2018, em dezembro, foi firmado aditamento para prever o que se chamou de Termo de Adesão Institucional, ${ }^{51}$ para resguardar trocas de informação entre autoridades internacionais e garantir o pagamento antecipado de valores no Brasil, caso eles sejam repactuados com autoridades internacionais. ${ }^{52}$

Além das obrigações descritas nos acordos anteriores, e de forma semelhante ao acordo da Odebrecht, o MPF passa a oferecer benefícios mais específicos: se obriga a requerer em juízo o levantamento de medidas cautelares patrimoniais e a peticionar em qualquer instância judicial ou administrativa para garantir a validade e eficácia do acordo, como autor ou fiscal da lei - ou seja, mesmo em ações propostas por terceiros, especificamente em ação civil pública e de Improbidade Administrativa. Também se obriga a não declarar a nulidade de contratos celebrados com entidades públicas.

Diferente dos demais acordos de leniência que, como se verá no próximo capítulo, foram contestados por outras autoridades, o acordo de leniência da J\&F foi submetido a investigação pelo próprio MPF. Em outubro de 2017, o MPF instaurou procedimento administrativo para apurar eventual descumprimento do acordo de leniência. ${ }^{53}$ A investigação foi iniciada quando a Procuradoria-Geral da República solicitou a rescisão no acordo de colaboração premiada dos executivos do grupo, por omissão de fatos criminosos relevantes e eventual prática de insider trading, pendente de homologação pelo $\mathrm{STF}^{54}$

Caso fosse constatado o descumprimento do acordo de colaboração, o MPF poderia rescindir o acordo de leniência, conforme previsto em suas

51 Nele, o MPF reconhece o direito de acesso e autoriza o compartilhamento de provas entre instituição interessada e colaboradora, desde que respeite as cláusulas, sendo ressalvado direito de pleitear ressarcimentos complementares.

52 Foi instrumento necessário para cumprir tratado entre Brasil e Estados Unidos e, segundo a Procuradoria, para resguardar interesses nacionais. Para informe enviado pela Procuradoria-Geral da República em 8 de dezembro de 2018. Cf. http://www.mpf.mp.br/pgr/noticias-pgr/ acordo-de-leniencia-entre-ministerio-publico-federal-e-j-f-tem-novo-aditamento. Acesso em: 4 mar. 2019.

53 Informação disponível em: http://www.mpf.mp.br/df/sala-de-imprensa/noticias-df/mpf-df-vai-apurar-eventual-descumprimento-do-acordo-de-leniencia-da-j-f. Acesso em: 4 mar. 2019.

54 Disponível em: http://www.mpf.mp.br/pgr/noticias-pgr/pgr-rescinde-acordo-de-colaboracao-de-joesley-batista-e-ricardo-saud. Último acesso em: 4 maio 2019. 
cláusulas, acionando uma série de disposições do próprio acordo, como a previsão do vencimento antecipado da multa e a anulação de qualquer benefício de redução de penalidades. Atualmente, é aguardada decisão perante o Supremo Tribunal Federal sobre a rescisão dos acordos de colaboração de pessoas físicas para determinar como eles impactarão no acordo de leniência da pessoa jurídica. A pergunta aberta é se as provas coletadas no acordo de leniência permanecerão válidas.

\section{A ATUAÇÃO DO MPF EM ACORDOS DE LENIÊNCIA}

É possível constatar que ao longo dos cinco primeiros anos da Lei Anticorrupção, a celebração de acordos de leniência pelo MPF se expandiu e se refinou nas três funções analisadas.

Entre 2014 e meados de 2017, o MPF foi a única autoridade a firmar acordos de leniência. ${ }^{55}$ Ele formula sua própria competência sobre os acordos, com base no contexto da Operação Lava Jato, a experiência de atuação no CADE e de seus membros na esfera cível (via Lei de Improbidade Administrativa) e criminal. O contexto conturbado, o fortalecimento do MPF e as regras vagas dos acordos de leniência, em especial, sua conexão com outras matérias permitem esta movimentação do órgão. Cada novo acordo do MPF parece ganhar cláusulas mais específicas com obrigações de parte a parte, dando pistas que a experiência que as negociações complexas eram aproveitadas para configurar os próximos acordos e, também, consolidar sua própria posição.

55 Em ordem cronológica, os acordos homologados neste período foram firmados com: SOG Óleo e Gás, Construções e Comércio Camargo Côrrea, Carioca Christiani Engenharia S.A., Mullen Lowe Brasil Publicidade Ltda., Andrade Gutierrez Investimentos em Engenharia, Signus, Odebrecht S.A., Braskem, VRG Linhas Aéreas S.A., Rolls Royce, NM Engenharias e Construções Ltda., J\&F Investimentos S.A. Vide lista completa divulgado pelo MPF em: http://www.mpf.mp.br/atuacao-tematica/ccr5/coordenacao/colaboracoes-premiadas-e-acordos-de-leniencia/colaboracoes-premiadas-e-acordos-de-leniencia. Último acesso em: 25 jan. 2019. 
Tabela 5. Ressarcimento de danos em acordos celebrados pelo MPF (R \$ Milhões)

\begin{tabular}{|c|c|c|c|c|c|}
\hline & SOG & Camargo Corrêa & $\begin{array}{l}\text { Andrade } \\
\text { Gutierrez }\end{array}$ & Odebrecht & J\&F \\
\hline Valor & 15 & 700 & 1.000 & $\begin{array}{l}8.5 \% \text { Divisão com } \\
\text { autoridades suíças e } \\
\text { americanas ( } 10 \% \\
\text { cada) }\end{array}$ & 10.300 \\
\hline \multirow[t]{2}{*}{ Distribuição } & $50 \%$ Petrobras & $\begin{array}{l}90 \% \text { empresas } \\
\text { públicas lesadas* }\end{array}$ & $\begin{array}{l}90 \% \text { empresas } \\
\text { públicas lesadas* }\end{array}$ & $\begin{array}{l}97.5 \% \text { entes } \\
\text { públicos lesados }\end{array}$ & $\begin{array}{l}1.750 \text { ao BNDES } \\
1.750 \text { à União } \\
1.750 \text { à FUNCEF } \\
1.750 \text { à PETROS } \\
500 \text { à CEF } \\
500 \text { ao FGTS }\end{array}$ \\
\hline & $\begin{array}{l}50 \% \text { Fundo } \\
\text { Penitenciário } \\
\text { Nacional }\end{array}$ & $\begin{array}{l}10 \% \text { Lei } \mathrm{n}^{\circ} 9.613 / 98, \\
\text { art. } 7^{\circ}, \S 1^{\circ}\end{array}$ & $\begin{array}{l}10 \% \text { Lei }^{\circ} 9.613 / 98, \\
\text { art. } 7^{\circ}, \S 1^{\circ}\end{array}$ & $\begin{array}{l}2.5 \% \text { Lei n } \\
9.613 / 98, \text { art. } 7^{\circ}, \S 1^{\circ}\end{array}$ & $\begin{array}{l}2.300 \text { para } \\
\text { execução de } \\
\text { projetos sociais }\end{array}$ \\
\hline $\begin{array}{c}\text { Divisão entre } \\
\text { investigadores }\end{array}$ & N/A & \begin{tabular}{|l|} 
Divisão entre \\
investigações da \\
Lava Jato e VALEC/ \\
Ferrovia Norte-Sul. \\
$(89 \%$ e $11 \%$, aprox. $)$
\end{tabular} & $\begin{array}{l}\text { Divisão entre } \\
\text { investigação da } \\
\text { Lava Jato e das } \\
\text { demais reveladas } \\
\text { pelo acordo, por } \\
\text { decisão conjunta } \\
\text { dos MPs. } \\
\end{array}$ & $\begin{array}{l}\text { A partir da adesão } \\
\text { de outros MPs, é } \\
\text { possível transferên- } \\
\text { cia de destinação } \\
\text { dos recursos. }\end{array}$ & N/A \\
\hline \multirow[t]{2}{*}{$\begin{array}{l}\text { Abatimentos } \\
\text { ou } \\
\text { Compensações }\end{array}$} & $\begin{array}{l}\text { Abate } 1 \text { milhão a } \\
\text { cada } 10 \text { milhões } \\
\text { apreendidos, } \\
\text { sequestrados ou } \\
\text { perdidos em favor } \\
\text { da União (até limite } \\
\text { de } 10 \text { milhões) }\end{array}$ & N/A & $\begin{array}{l}\text { Valores em } \\
\text { processos } \\
\text { administrativos ou } \\
\text { cíveis, exceto de } \\
\text { escopo tributário. }\end{array}$ & $\begin{array}{l}\text { Pagamentos a } \\
\text { vítimas e terceiros, } \\
\text { incluindo bloqueios } \\
\text { e transações. }\end{array}$ & $\begin{array}{l}\text { Multas e } \\
\text { ressarcimentos, } \\
\text { incluindo assuntos } \\
\text { tributários. } \\
\text { Valores pagos por } \\
\text { pessoas físicas em } \\
\text { função de acordos } \\
\text { de colaboração. } \\
\text { Saldos de contas } \\
\text { bancárias } \\
\text { repatriadas. }\end{array}$ \\
\hline & N/A & N/A & N/A & N/A & $\begin{array}{l}\text { Abatimento } \\
\text { limitado até } 80 \% \text { do } \\
\text { valor total. }\end{array}$ \\
\hline
\end{tabular}

Elaborado pela autora

O protagonismo inicial do MPF também condiciona a atuação das demais autoridades. Porém, para Rodriguez, é a partir do acordo da J\&F e da eventual rescisão com as pessoas físicas que a balança do poder mudou e outras burocracias estatais puderam emergir como legítimas para realizar acordos de leniência. ${ }^{56}$ Para entender essa emergência, é preciso voltar a 2014. 